\title{
KORELASI ANTARA KEMANDIRIAN DENGAN HASIL BELAJAR MATEMATIKA PADA PESERTA DIDIK
}

\author{
Ila Lestari ${ }^{1}$, Arie Purwa Kusuma ${ }^{2}$, Desy Bangkit Arihati ${ }^{3}$ \\ 1, 2, 3Sekolah Tinggi Keguruan dan Ilmu Pendidikan (STKIP) Kusuma Negara Jakarta \\ arie pk@stkipkusumanegara.ac.id
}

\begin{abstract}
Abstrak
Tujuan dari penelitian ini adalah untuk mengetahui adanya hubungan kemandirian dengan hasil belajar matematika pada materi relasi dan fungsi dikelas Vlll SMP PGRI 285 Jonggol. Metode penelitian yang digunakan adalah metode deskriftif dengan pendekatan korelasi. Instrumen yang digunakan dalam penelitian ini adalah instrument tes, berupa angket pernyataan dan tes obyektif dengan 30 butir soal. Skor benar bernilai 1 dan skor salah bernilai 0 . Uji persyaratan analisis data meliputi uji normalitas dengan menggunakan uji liliefors dengan hasil Lhitung $=0.122 ;$ Ltabel $=$ 0.162 dengan taraf signifikan 0.05 untuk variable $X$. Dan Lhitung $=0.122 ; L_{\text {tabel }}=0.162$ dengan taraf signifikan 0.05 untuk variable Y. Berarti semua populasi berdistribusi normal.Uji hipotesis menggunakan rumus Korelasi Product Moment dengan hasil perhitungan rhitung $=0.96$ dengan koefisien determinasi sebesar 25,1\%. Berdasarkan uji signifikan diperoleh thitung $=3,54$, sedangkan $t$ tabel $=1,701$ dengan demikian terdapat hubungan yang signifikan antara hubungan kemandirian dengan hasil belajar matematika pada materi relasi dan fungsi di kelas VIII SMP PGRI Jonggol. Dengan demikian dapat disimpulkan bahwa terdapat hubungan yang positif antara kemandirian dengan hasil belajar pada materi relasi dan fungsi di kelas Vlll SMP PGRI Jonggol sebanyak 25,1\%.
\end{abstract}

Kata kunci : Hasil belajar, Kemandirian Belajar, dan Korelasi.

\section{PENDAHULUAN}

Pendidikan merupakan salah satu faktor penunjang keberhasilan pembangunan yang sangat penting. Pendidikan senantiasa menjadi perhatian utama dalam rangka memajukan kehidupan generasi demi generasi sejalan dengan tuntutan kemajuan masyarakatnya. Kemajuan dalam satuan waktu jangka panjang akan dapat memprediksi kualitas bangsa pada sekian puluh tahun ke depan. Sehingga sangat wajar jika kemajuan suatu bangsa dapat dilihat seberapa besar perhatian bangsa tersebut terhadap pendidikan.

Berhubungan dengan tujuan nasional pendidikan bagi bangsa untuk memperoleh pendidikan yang maju, tinggi, dan berkembang maka perlunya suatu perencanaan. Sebagaimana tercantum di dalam Undang-Undang Republik Indonesia Nomor 20 Tahun 2003 tentang Sistem Pendidikan Nasional BabII Pasal 3, berbunyi: 
Pendidikan nasional berfungsi mengembangkan kemampuan dan membentuk watak serta peradaban bangsa yang bermartabat dalam rangka mencerdaskan kehidupan bangsa, bertujuan untuk berkembangnya potensi peserta didik agar menjadi manusia yang beriman dan bertakwa kepada Tuhan Yang Maha Esa, berakhlak mulia, sehat, berilmu, cakap, kreatif, mandiri, dan menjadi warga negara yang demokratis serta bertanggung jawab.

Tujuan pendidikan sebagai suatu komponen pendidikan nasional yang menduduki posisi penting diantara komponen-komponen pendidikan lainnya Dapat dikatakan bahwa seluruh komponen dari seluruh kegiatan pendidikan dilakukan semata-mata terarah kepada atau ditujukan untuk pencapaian tujuan tersebut. Oleh karena itu untuk mewujudkan tujuan pendidikan tersebut maka diselenggarakan rangkaian kependidikan secara sengaja, berencana, terarah, berjenjang, dan sistematis melalui lembaga formal. Sekolah merupakan salah satu bentuk pendidikan formal yang mengemban amanat bangsa untuk menyiapkan sumber daya manusia yang berkualitas.

Sekolah berusaha dengan segala cara agar peserta didik mendapat hasil proses belajar yang sebaik-baiknya.
Dengan demikian faktor-faktor yang dapat mempengaruhi proses belajar mengajar di lingkungan sekolah antara lain peserta didik, tenaga pendidikan, biaya, sarana dan prasarana, serta lingkungan. Keberhasilan atau kegagalan sangat bergantung kepada peserta didik, bagaimana kemampuan dan kesiapan peserta didik dalam mengikuti kegiatan belajar serta minat dan sikap peserta didik dalam proses belajar mengajar. Faktor keluarga pun juga ikut mempengaruhi hasil kegiatan belajar mengajar. Berfokus pada sekolah, sebagai pusat pendidikan.

Apabila faktor-faktor tersebut dapat dipenuhi sudah tentu akan memperlancar proses belajar mengajar, yang dapat menghasilkan pencapaian hasil belajar yaitu lulusan sekolah yang bermutu. Berbicara mengenai mutu pendidikan berarti secara tidak langsung menyinggung peran aktif seorang guru di dalam kelas. Oleh karena itu, guru harus memiliki kemampuan mengelola kelas baik sebagai motivator, inisiator, mediator, informator, dan fasilitator bagi peserta didiknya sehingga akan terwujud suasana belajar yang aktif, mandiri dan menyenangkan.

Kegiatan belajar yang aktif dan menyenangkan merupakan salah satu faktor yang berpengaruh pada hasil belajar peserta didik. Hasil belajar merupakan sebuah kondisi yang 
menggambarkan tingkat keberhasilan belajar di sekolah. Hasil belajar bukan sebagai tujuan akhir dari sebuah proses belajar. Namun kegiatan belajar yang baik secara langsung maupun secara tidak langsung selalu mengarah kepada pencapaian hasil yang tinggi, salah satunya yaitu matematika.

Matematika merupakan ilmu dasar yang mempunyai peranan penting dalam perkembangan ilmu pengetahuan dan teknologi, serta bagi mata pelajaran inti lainnya. Mata pelajaran matematika perlu diberikan kepada semua peserta didik dari sekolah dasar untuk membekali peserta didik dengan kemampuan berfikir logis, analitis, sistematis, kreatif, serta kemampuan bekerja sama. Mengingat pentingnya peranan matematika tersebut maka di Indonesia pelajaran matematika diberikan pada setiap jenjang pendidikan, mulai dari pendidikan dasar sampai perguruan tinggi yang memiliki tujuan dalam pembelajaran tersebut.

Tujuan pembelajaran salah satunya adalah hasil belajar berupa pemahaman terhadap matematika. Pemahaman merupakan salah satu tujuan yang hendak didapat, terlebih lagi pemahaman konsep. Berkenaan dengan pentingnya pemahaman konsep dalam belajar matematika di Permendiknas No. 22 tentang standar isi, ditegaskan bahwa salah satu tujuan pembelajaran matematika di sekolah ialah agar peserta didik memahami konsep dalam matematika, menyatakan keterkaitan antar konsep dan mengaplikasikan konsep atau algoritma secara luwes. akurat, efisien, dan tepat dalam pemecahan masalah (Sri Wardhani; 2008). Jadi, sangatlah penting pemahaman konsep dalam belajar matematika. Berdasarkan wawancara yang penulis lakukan dengan salah satu guru matematika di SMP PGRI 285 Jonggol, ternyata peserta didik kurang dalam kemandirian dengan hasil belajar pelajaran matematika materi relasi dan fungsi sehingga berpengaruh terhadap hasil belajar matematika. Dengan berakhirnya suatu proses belajar maka peserta didik memperoleh suatu hasil belajar. Hasil belajar merupakan faktor penting dalam pendidikan secara langsung atau tidak langsung, guru maupun peserta didik selalu mengharapkan hasil belajar peserta didiknya. Masyarakat dan orang tua murid tidak mau tau tentang proses belajar mengajar di kelas yang mereka harapkan dan perhatikan hanyalah hasil belajar. Menurut Dimyati dan Mudjiono, "Hasil belajar merupakan puncak dari proses belajar". Hasil belajar juga merupakan hasil proses belajar ataupun proses pembelajaran. Hasil belajar juga merupakan hal yang di pandang dari dua sisi. Dari sisi peserta didik hasil belajar merupakan 
berakhirnya puncak pada proses belajar. Hasil belajar merupakan hasil pembelajaran dan dari sisi guru bahwa tindak mengajar di akhiri dengan proses evaluasi hasil belajar.(5)

Kendala-kendala yang dihadapi oleh peserta didik di sekolah tersebut ternyata terjadi dilingkungan peserta didik kelas VIII. Diketahui bahwa kemampuan belajar matematika pada materi relasi dan fungsi pada tahun pelajaran 2017/2018 menurut pengamatan sementara dapat dikatakan rendah dengan nilai ratarata hasil ulangan harian 65 yang belum sesuai dengan nilai KKM Ulangan Harian yaitu 75 .

Hal tersebut dikarenakan peserta didik kurang mempunyai kemandirian belajar yang baik untuk mencapai KKM tersebut. Akan tetapi pada kenyataannya, nilai tersebut akan menjadi tuntas dalam rapor sesuai dengan KKM dikarenakan sebagai prasyarat kelulusan peserta didik SMP. Untuk dapat memperoleh hasil belajar yang memuaskan diperlukan adanya kemandirian belajar yang baik. Kemandirian belajar memberikan pengaruh yang positif bagi peserta didik dan dapat membiasakan diri untuk selalu bertanggung jawab atas apa yang menjadi tanggung jawabnya, tidak bergantung pada orang lain, mempunyai rasa percaya diri yang tinggi, dan penuh inisiatif dalam memecahkan masalah (tugas sekolah). Kemandirian berasal dari kata dasar diri yang mendapatkan awalan kedan akhiran -an yang kemudian membentuk suatu kata keadaan atau kata benda. Dalam Kamus Besar Bahasa Indonesia mandiri adalah "berdiri sendiri"(1) . Sedangkan belajar "belajar ialah suatu proses usaha yang dilakukan individu untuk memperoleh suatu perubahan tingkah laku yang baru secara keseluruhan sebagai hasil pengalaman individu itu sendiri dalam interaksi dengan lingkungan" (2). Hal ini terbukti dari cara belajar peserta didik yang memiliki inisiatif akan memacu diri untuk belajar secara terus-menerus. Disamping itu, peserta didik mampu memilih kegiatan belajar sendiri dengan penuh tanggung jawab serta percaya diri.

Kemandiran dalam belajar bertumpu pada prinsif bahwa setiap individu yang belajar hanya akan sampai kepada perolehan hasil belajar, mulai dari keterampilan, pengembangan penalaran, pembentukan sikap sampai kepada penemuan diri sendiri, apabila peserta didik mengalami sendiri dalam proses perolehan hasil belajar tersebut.

Guru mempunyai tugas yang harus dilaksanakan sesuai dengan profesinya yaitu mendesain sedemikian rupa cara mengajarnya dengan pengajar yang bisa 
meningkatkan motivasi dalam pembelajaran matematika. Proses pembelajaran mata pelajaran matematika pendekatan dan metode yang biasa digunakan guru di SMP PGRI 285 Jonggol yaitu: pendekatan konvensional dengan metode ceramah, diskusi, dan tanya jawab serta suasana pembelajaran membuat peserta didik menjadi bosan karena hanya menjadi pendengar setia dan penerima informasi yang pasif tanpa adanya interaksi timbal balik antara guru dan peserta didik. Sehingga hasil belajar matematika materi relasi dan fungsi peserta didik selama ini kurang baik karena kurang mengerti tentang kemandirian dan hasil belajar dan juga pendekatan serta suasana belajar yang kurang menyenangkan bagi peserta didik.

\section{METODE}

Penelitian ini menggunakan metode kuantitatif dengan pendekatan korelasional, yaitu ingin mengetahui hubungan kemandirian dengan hasil belajar matematika pada materi relasi dan fungsi di kelas VIII SMP PGRI 285 Jonggol. Populasi adalah subyek yang berada pada suatu wilayah dan memenuhi syarat-syarat tertentu berkaitan dengan masalah atau objek penelitian. Populasi merupakan salah satu hal yang sangat diperlukan dalam penelitian, sebab melalui populasi itulah data yang diperlukan oleh peneliti didapat. Populasi dibedakan menjadi dua yaitu: a. Populasi Target, Seluruh peserta didik SMP PGRI 285 Jonggol yaitu sebanyak 450 peserta didik yang terdaftar sebagai murid di sekolah tersebut pada semester ganjil tahun pelajaran 20182019. b.Populasi Terjangkau Seluruh peserta didik kelas VIII SMP PGRI 285 Jonggol yaitu kelas VIII-A sampai dengan VIII-E sebanyak 150 peserta didik. Sampel adalah suatu proses pengambilan data, dimana hanya sebagian populasi saja yang diambil dan dipergunakan untuk menentukan sifat serta ciri yang dikehendaki dari suatu populasi. Oleh karena itu, yang menjadi sampel dalam penelitian ini adalah 30 peserta didik yang diambil dari populasi terjangkau. Teknik pengambilan sampel dalam penelitian ini menggunakan teknik random sampling yaitu teknik pengambilan sampel secara acak untuk memberikan peluang atau kesempatan sama bagi setiap unsur atau anggota populasi untuk dipilih menjadi sampel.

Sesuai dengan jumlah variabel yang diteliti, peneliti menggunakan dua jenis data. Data yang digunakan adalah skor yang diperoleh dari tes hasil belajar Kemandirian dengan hasil belajar matematika pada materi relasi dan fungsi yang dikerjakan peserta didik. Berdasarkan tujuan penelitian yaitu apakah terdapat hubungan antara kemandirian dengan hasil 
belajar matematika pada materi relasi dan fungsi, maka penulis membuat instrument penguasaan materi relasi dan fungsi untuk mendapatkan data. Instrumen ini menggunakan tes obyektif dengan tipe pilihan ganda sebanyak 30 butir soal. Tiap soal terdiri dari empat pilihan jawaban yaitu a, b, c, dan d. Pemberian skor untuk jawaban benar adalah satu, sedangkan jawaban salah diberi angka nol. Instrumen yang digunakan untuk konsep perbandingan maupun skala berupa tes dengan tipe pilihan ganda sebanyak 30 butir soal. Tiap butir soal terdiri dari empat pilihan ganda yaitu $\mathrm{a}, \mathrm{b}, \mathrm{c}$,dan $\mathrm{d}$. Instrumen ini mengukur aspek dengan kategori pengetahuan dan kemandirian peserta didik dalam proses belajar. Uji validitas dan reliabilitas instrumen dilakukan di kelas VIII SMP PGRI 285 Jonggol. 5. Teknik Persyaratan Analisis Data Teknik analisis data dilakukan dengan uji regresi dan korelasi. Sebelum melaksanakan analisis data terlebih dahulu dilaksanakan uji persyaratan analisis data yaitu uji normalitas dan uji linieritas. Baru sleanjutnya dilakukan uji t.

\section{HASIL PENELITIAN DAN PEMBAHASAN}

\section{A. Data Hasil Penelitian}

Berdasarkan penelitian yang peneliti lakukan terhadap peserta didik kelas VIII SMP PGRI 285
Jonggol. Setelah dilakukan uji validitas dan reliabilitas soal di uji kepada kelas sampel. Kemudian selanjutnya hasilnya dilakukan uji normalitas dan uji linieritas, Uji Normalitas digunakan untuk mengetahui apakah data terdistribusi secara normal atau tidak. Uji normalitas dilakukan pada kedua variabel yaitu Kemandirian Belajar (X) dan Hasil Belajar Matematika Pada Materi Relasi dan Fungsi (Y) menggunakan uji Lilliefors. Dari perhitungan pada tabel uji normalitas diambil nilai tertinggi harga mutlak selisih $\mathrm{F}(\mathrm{Zi})$ dan $\mathrm{S}(\mathrm{Zi})$ yang disebut sebagai Lhitung. Daftar nilai kritis untuk uji lilliefors pada taraf signifikan $(\alpha=0,05)$ dan $\mathrm{n}=30$ adalah 0,162 sebagai Ltabel. Kriteria pengujian $\mathrm{HO}$ diterima apabila Lhitung ( Lh ) < Ltabel (Lt) yang berarti data berasal dari populasi yang berdistribusi normal dan $\mathrm{H} 0$ ditolak apabila Lhitung (Lh ) > Ltabel (Lt) yang berarti data berasal dari populasi yang berdistribusi tidak normal. Variabel X, dari perhitungan uji normalitas yang telah dilakukan diperoleh nilai $\mathrm{Lh}=$ 0,068 sedangkan dalam tabel liliefors pada taraf signifikan 0,05 dan $\mathrm{n}=30$ yaitu $\mathrm{Lt}=0,122$, ini berarti bahwa $\mathrm{Lh}<$ Lt $(0,122<0,162)$. Jadi dapat dikatakan bahwa data variabel $X$ berdistribusi normal. Variabel $Y$, dari perhitungan uji normalitas pada variabel $Y$ didapatkan nilai $\mathrm{Lh}=0,151$ dan tabel liliefors pada taraf signifikan 0,05 dan 
$\mathrm{n}=30$ menunjukan Lt $=0,162$, oleh karena itu $\operatorname{Lh}<\operatorname{Lt}(0,122<0,162)$. Jadi keputusannya adalah data variabel $\mathrm{Y}$ juga berdistribusi normal. Kedua hasil perhitungan uji normalitas pada variabel $\mathrm{X}$ dan $\mathrm{Y}$ diatas dapat lebih jelah terlihat pada Tabel 4.3

Tabel 4.3 Uji Normalitas

\begin{tabular}{|c|c|c|c|c|}
\hline Variabel & $\mathbf{N}$ & $\begin{array}{c}\text { Lhitung } \\
\left(\mathbf{L}_{\mathbf{o}}\right)\end{array}$ & $\left.\mathbf{L t a b e l}_{\mathbf{( L t}}\right)$ & Simpulan \\
\hline $\mathrm{X}$ & 30 & 0,122 & 0,162 & $\begin{array}{c}\text { Data } \\
\text { Berdistribusi } \\
\text { Normal }\end{array}$ \\
\hline $\mathrm{Y}$ & 30 & 0,122 & 0,162 & $\begin{array}{c}\text { Data } \\
\text { Berdistribusi } \\
\text { Normal }\end{array}$ \\
\hline
\end{tabular}

Uji linearitas pada penelitian ini digunakan untuk mengetahui apakah terdapat hubungan yang linear atau tidak pada kedua variabel. Hasil uji linearitas sederhana terhadap variabel Kemandirian $(X)$ dengan hasil belajar matematika materi Relasi dan Fungsi (Y) menghasilkan koefisien arah regresi sebesar 0,99 dan konstanta sebesar 4,83. Maka bentuk hubungan antara variabel perbandingan (X) dengan skala $(\mathrm{Y})$ memiliki persamaan regresi sebagai berikut:

$\hat{Y}=15,17+0,83 X$

Berdasarkan persamaan di atas telah diketahui bahwa setiap kenaikan satu nilai Kemandirian (X) dapat menyebabkan kenaikan nilai hasil belajar matematika (Y) sebesar 0,83, sehingga membentuk gambar kurva yang menunjukan bahwa kedua variabel memiliki hubungan yang linear dan positif karena titik-titik membentuk garis lurus dan mengarah dari kiri ke kanan atas. Untuk lebih jelas persamaan regresi $\hat{Y}=$ $15,17+0,83 \mathrm{X}$ terlihat pada gambar berikut:

Gambar 4.3 Grafik Persamaan Regresi Linear Sederhana

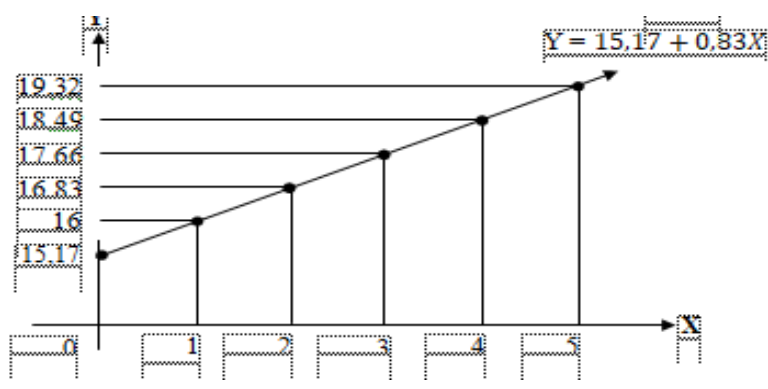

Selanjutnya dari perhitungan uji linieritas juga diketahui bahwa nilai Fhitung $=0,96$ dan $F_{\text {tabel }}$ dengan taraf signifikasi $\alpha=0,05$ dan untuk pembilang $\mathrm{dkTC}=10$, untuk penyebut $\mathrm{dk}$ Err $=18$, diperoleh harga $\mathrm{F}_{\text {tabel }}=$ 2,41 . Jika dikonsultasikan dengan harga $F_{\text {tabel }}$ karena $F_{\text {hitung }}<\mathrm{F}_{\text {tabel }}=(0,99<$ 2,41), maka H0 diterima. Dengan demikian hubungan $\mathrm{X}$ dan $\mathrm{Y}$ adalah linier.

Setelah uji pra syarat terpenuhi maka dilakukan uji selanjutnya yaitu uji t. Hubungan antara Kemandirian belajar $(X)$ dengan hasil belajar Matematika materi Relasi dan Fungsi (Y) dari hasil perhitungan koefisien korelasi diperoleh korelasi sederhana rxy $=0,501$. Hasil tersebut jika dikaitkan dengan angka indeks korelasi product moment masuk dalam 
kategori hubungan yang cukup kuat. Hasil perhitungan dan tabel indeks dapat dilihat pada lampiran.

Selanjutnya dari hasil koefisien korelasi dilakukan uji keberartian (signifikansi) koefisien korelasi kemandirian dalam belajar $(\mathrm{X})$ dengan hasil belajar Matematika materi Relasi dan Fungsi (Y) dengan menggunakan uji-t. Dari perhitungan uji-t diperoleh thitung sebesar 3,54, sedangkan untuk ttabel pada taraf signifikan 0,05 dengan $\mathrm{dk}(\mathrm{n}-2)=(30-2)=28$ sebesar 1,701. Kriteria pengujian H0 diterima apabila thitung < ttabel yang berarti kedua variabel tidak terdapat hubungan yang signifikan dan $\mathrm{H} 0$ ditolak apabila thitung $>$ tabel yang berarti kedua variabel terdapat hubungan yang signifikan.

Berdasarkan uraian di atas, maka dapat disimpulkan bahwa thitung lebih besar dari ttabel $(3,54>1,701)$, artinya H0 ditolak dan dapat dikatakan bahwa terdapat hubungan yang signifikan antara kemandirian dalam belajar dengan hasil belajar matematika pada materi Relasi dan Fungsi dengan koefisien korelasi determinasi (rxy2) sebesar 0,251. Hal ini berarti sebesar 25,1\% hasil belajar Matematika materi Relasi dan fungsi (Y) dipengaruhi oleh kemandirian dalam belajar $(X)$.

\section{Pembahasan Hasil Penelitian}

Penelitian ini merupakan penelitian korelasi, yaitu mencari tahu hubungan antar variabel yang diteliti. Variabel penelitian ini terbagi menjadi dua yaitu kemandirian belajar sebagai variabel bebas $(X)$ dan variabel hasil belajar matematika pada materi Relasi dan Fungsi sebagai variabel terikat (Y). Untuk menjaring data peneliti menggunakan instrumen angket berupa kuisioner dengan penilaian menggunakan skala likert 1-4 untuk variabel (X). Sedangkan untuk menjaring data pada variabel (Y), peneliti menggunakan instrumen soal pilihan ganda dengan jawaban benar bernilai 1 dan salah bernilai 0 . Instrumen angket berjumlah 30 butir pertanyaan dan instrumen soal pilihan ganda sebanyak 30 butir pertanyaan. Kedua instrumen tersebut di lakukan tes pada 30 peserta didik kelas VIII yang terpilih, lebih jelasnya bisa dilihat pada lampiran.

Setelah dilakukan tes pada 30 orang peserta didik kelas VIII SMP PGRI 285 Jonggol didapatkan hasil nilai yang cukup beragam. Kemudian berdasarkan hasil perhitungan statistik yang dilaksanakan bahwa hasil yang diperoleh menunjukan hubungan yang linier karena menghasilkan persamaan positif $\hat{Y}=15,17+0,83 X$ dan Fhitung $>F_{\text {tabel }}(0,99<2,41)$, sedangkan koefisien korelasi product moment dalam penelitian ini didapat dari 
sampel yaitu rxy $=0,501$ termasuk kategori cukup kuat jika dikonsultasikan dengan tabel interpretasi angkat $\mathrm{r}$ product moment dalam interval 0,400 - 0,600. Dan dari hasil perhitungan pengujian hipotesis dapat dinyatakan bahwa thitung $>t_{\text {tabel }}$ $(3,54>1,701)$ maka H0 ditolak yang berarti terdapat hubungan antara Kemandirian dengan hasil belajar matematika pada materi Relasi dan Fungsi.

Besar kecilnya hubungan ini ditentukan oleh koefisien determinasi hanya sebesar 25,1\% yang berarti kontribusi yang diberikan kemandirian belajar terhadap hasil belajar matematika pada materi Relasi dan Fungsi hanya 25,1\%. Dari kontribusi sebesar ini, menunjukkan bahwa tidak hanya kemandirian belajar saja yang memberikan kontribusi terhadap hasil belajar matematika pada materi Relasi dan Fungsi, namun masih ada $74,9 \%$ faktor lain yang memberikan kontribusi terhadap hasil belajar matematika pada materi Relasi dan Fungsi kelas VIII selain dari kemandirian dalam belajar. Sehingga dapat diinterpretasikan bahwa semakin baik kemandirian dalam belajar maka akan semakin baik pula hasil belajar matematika materi Relasi dan fungsi yang akan diperoleh.

\section{SIMPULAN}

Berdasarkan hasil penelitian dapat disimpulkan bahwa terdapat hubungan positif antara Kemandirian Dalam Belajar Terhadap Hasil Belajar Matematika Materi Relasi dan Fungsi di SMP PGRI 285 Jonggol. Hal ini dibuktikan dengan nilai koefisien korelasi yang didapat yaitu $\mathrm{r}_{\mathrm{xy}}=0,501$. Kemudian diperkuat dengan uji $t$ yang didapat yaitu thitung $=3,54$. Besar kontribusi variabel (X) (kemandirian belajar) terhadap variabel (Y) (hasil belajar Matematika materi relasi dan fungsi) dilihat dari besarnya angka koefisien determinasi yaitu sebesar 0,251 atau 25,1\%. Sehingga 25,1\% hasil belajar Matematika materi relasi dan fungsi ditentukan oleh Kemandirian dalam belajar sedangkan sisanya ditentukan oleh faktor lain seperti fakor kemampuan dasar matematika peserta didik, faktor gaya belajar, faktor guru yang mengajar, faktor penguasaan materi sebelumnya dan sebagainya .

\section{DAFTAR PUSTAKA}

Abu Ahmadi dan Widodo Supriyono. 1991. Psikologi Belajar. Jakarta: PT.RINEKA CIPTA.

Arikunto, Suharsimi. 2006. Prosedur Penelitian Suatu Pendekatan Praktik. Jakarta: Rineka Cipta. 
Rahmawati, N. K., \& Kusuma, A. P. (2019). Hubungan Pemahaman Konsep Aritmatika Sosial Dengan Hasil Belajar IPS Materi PPH. Buana Matematika: Jurnal Ilmiah Matematika Dan Pendidikan Matematika, 9(1:), 1-6.

Departemen Pendidikan Nasional. 2008. Kamus Besar Bahasa Indonesia Edisi Keempat. Jakarta: PT Gramedia Pustaka Utama.

Mudjiman, Haris. 2007. Belajar Mandiri (Self-motivated Learning). Jawa Tengah: UNS Press.

Sudjana. 2003. Penilaian Hasil Proses Belajar Mengajar. Bandung: Remaja Rosdakarya.
Sukino, Simangungungsong. 1994. Matematika SMP Kelas VIII jilid 2 A. Jakarta: Erlangga.

Supardi U.S. 2012. Aplikasi Statistik dalam Penelitian. Jakarta: Ufuk Pres.

Tirtarahardja, Umar. 2005. Pengantar Pendidikan. Jakarta: PT Rineka Cipta.

Wardhani, Sri. 2008. Analisis SI dan SKL Mata Pelajaran Matematika SMP/MTs untuk Optimalisasi Tujuan Mata Pelajaran Matematika. Yogyakarta: Pusat Pengembangan dan Pemberdayaan Pendidikan dan Tenaga Kependidikan Matematika. 